\title{
Prostate Basal Cell Carcinoma: A Case Report
}

\author{
Sahoko Ninomiya ${ }^{a}$ Takashi Kawahara $^{a}$ Hiromichi Iwashita $^{b}$ \\ Genta Iwamoto $^{a}$ Daiji Takamoto $^{a}$ Taku Mochizuki $^{a}$ \\ Shinnosuke Kuroda ${ }^{a}$ Teppei Takeshima ${ }^{a}$ Koji Izumi ${ }^{a}$ \\ Jun-ichi Teranishi ${ }^{a}$ Yasushi Yumura ${ }^{a}$ Yasuhide Miyoshi ${ }^{a} \quad$ Takuo Asai $^{c}$ \\ Hiroji Uemura ${ }^{a}$ \\ ${ }^{a}$ Departments of Urology and Renal Transplantation, Yokohama City University Medical \\ Center, Yokohama, Japan; ${ }^{b}$ Department of Diagnostic Pathology, Yokohama City \\ University Medical Center, Yokohama, Japan; 'Department of Urology, Ohguchi Higashi \\ General Hospital, Yokohama, Japan
}

\section{Keywords}

Prostate basal cell carcinoma - Basal cell cancer $\cdot$ Dysuria $\cdot$ Non-adenocarcinoma

\begin{abstract}
Prostate basal cell carcinoma (PBCC) accounts for $0.01 \%$ of all prostate cancers. A 68 -yearold man complained of dysuria for 5 years on his initial visit. His PSA level was $3.87 \mathrm{ng} / \mathrm{mL}$. Due to a diagnosis of benign prostate hyperplasia, he underwent transurethral resection of the prostate. A pathological examination revealed that basal cell-like atypical cells made alveolar with palisadal layout. Immunohistochemical analysis showed positive $34 \beta 12, \mathrm{P} 63$, and $\mathrm{Ki}-67$. Based on these findings, PBCC was diagnosed. Then, we performed radical prostatectomy. He was free from recurrence 22 months after the operation. We herein report an extremely rare case of PBCC.




\section{Introduction}

Prostate basal cell carcinoma (PBCC) accounts for $0.01 \%$ of all prostate cancers. PBCC usually shows no PSA elevation, and in most cases, PBCC is diagnosed by chief complaints of lower urinary tract symptoms or gross hematuria [1-3]. A diagnosis of PBCC is difficult based on a pathological examination using hematoxylin and eosin staining alone, and immunohistochemical staining is typically needed [4]. We herein report an extremely rare case of PBCC.

\section{Case Presentation}

A 68-year-old man complained of dysuria for 5 years in his initial visit. His PSA level was $3.87 \mathrm{ng} / \mathrm{mL}$. Due to a diagnosis of benign prostate hyperplasia, he underwent transurethral resection of the prostate. Histopathology of the resected specimens suggested PBCC.

He was referred to our hospital for further treatment. Because of the lack of any findings of distal metastasis, he received radical prostatectomy in December 2016 (Fig. 1). A laboratory examination showed values within normal limits for PSA, SCC, and NSE $(<0.01,0.8$, and $13.3 \mathrm{ng} / \mathrm{mL}$, respectively).

A pathological examination revealed that basal cell-like atypical cells made alveolar with palisadal layout (Fig. 1, 2). Immunohistochemical analysis showed positive 34ß12, P63, and Ki-67 (Fig. 3). Bcl-2 also showed positive expression in PBCC. Based on these findings, PBCC was diagnosed. No tumor cells were observed in the dissected lymph nodes. He was free from recurrence 22 months after operation.

\section{Discussions}

PBCC is a rare disease, accounting for $0.01 \%$ of all prostate cancers [1]. It was first described in 1974, and thus far, fewer than 100 cases have been reported [2, 4-7]. Previous reports on PBCC have noted a mean age of 50-64 years, but a wide age range from 28 to 78 years has been described. Although categorized as prostate cancer, most patients show normal PSA levels [2, 4, 7-10]. PBCC usually shows heterogeneity, like prostate adenocarcinoma, on T2-weighted magnetic resonance imaging (MRI) [11]. In the present case, MRI detected T3 stage and no apparent lymph node metastasis (Fig. 4). The patient's chief complaints were lower urinary tract symptoms, gross hematuria, and a hard prostate nodule $[8$, 12]. PBCC was incidentally diagnosed using specimens from TUR-P, which had been performed for his lower urinary tract symptoms.

Histologically, infiltrating basaloid cells form dilated acinar and cribriform spaces with occasional glandular, trabecular, or solid areas $[9,10]$. Stearns et al. [10] reported a case of basal cell carcinoma appearing as a neuroendocrine tumor that was treated with etoposide and cisplatin chemotherapy. PBCC usually arises from the transitional zone of the prostate, and a pathological diagnosis can be difficult, with immunohistochemical staining typically needed [1]. The basal cell lesions are positive for p63 and cytokeratin (34bE12). Ki-67 is used to detect malignancy, and a higher expression of Ki-67 (more than 20\%) is needed to detect PBCC $[1,2]$. HER2 has been reported to be positive in some cases of PBCC, but negative cases have also been reported, so HER2 is not used for diagnostic purposes. Trastuzumab has been administered in some HER2-positive cases but has shown no efficacy [13]. 
Reported treatments for PBCC include radical prostatectomy, chemotherapy, and radiotherapy. Radical prostatectomy might be a curative treatment option for localized prostate cancer $[10,14]$. Direct invasion to the surrounding organs and liver metastasis have been reported at the time of the diagnosis, so radical prostatectomy was not able to be performed in most cases. Cases treated with radiotherapy, systemic chemotherapy, hormonal therapy, and surgical castration have been described, but no adequate therapy has been established. Androgen receptor was negative in some reported PBCC cases, and hormonal therapy including bicalutamide was not found to be effective [13]. Our case was also negative for androgen receptor. However, no other established treatments have been reported.

Metastatic lesions have been reported in the liver and lung [6]. At the time of the diagnosis, the present case had no invasion and no distant metastasis, so radical prostatectomy was performed. Due to the lack of evidence supporting adjuvant therapy, follow-up CT has been performed every 3 months. The patient was free from recurrence 15 months after operation.

\section{Conclusion}

We encountered a case of PBCC diagnosed by the evaluation of a specimen obtained through TUR-P, and the patient was free from recurrence 15 months after radical prostatectomy.

\section{Statement of Ethics}

The present study was approved by the IRB of Yokohama City University Medical Center and written informed consent was obtained from the patient for publication of this case report and any accompanying images.

\section{Disclosure Statement}

The authors declare no conflict of interests.

\section{References}

1 Komura K, Inamoto T, Tsuji M, Ibuki N, Koyama K, Ubai T et al. Basal cell carcinoma of the prostate: unusual subtype of prostatic carcinoma. Int J Clin Oncol. 2010 Dec;15(6):594-600.

2 Tsuruta K, Funahashi Y, Kato M. Basal cell carcinoma arising in the prostate. Int J Urol. 2014 Oct;21(10):1072-3.

3 Sadahira T, Wada K, Araki M, Ishii A, Watanabe T, Nasu Y et al. Impact of selective media for detecting fluoroquinolone-insusceptible/extended-spectrum beta-lactamase-producing Escherichia coli before transrectal prostate biopsy. Int J Urol. 2017 Dec;24(12):842-7.

4 Chang K, Dai B, Kong Y, Qu Y, Wu J, Ye D et al. Basal cell carcinoma of the prostate: clinicopathologic analysis of three cases and a review of the literature. World J Surg Oncol. 2013 Aug;11(1):193.

5 Ayyathurai R, Civantos F, Soloway MS, Manoharan M. Basal cell carcinoma of the prostate: current concepts. BJU Int. 2007 Jun;99(6):1345-9.

6 Segawa N, Tsuji M, Nishida T, Takahara K, Azuma H, Katsuoka Y. Basal cell carcinoma of the prostate: report of a case and review of the published reports. Int J Urol. 2008 Jun;15(6):557-9.

7 Ahuja A, Das P, Kumar N, Saini AK, Seth A, Ray R. Adenoid cystic carcinoma of the prostate: case report on a rare entity and review of the literature. Pathol Res Pract. 2011 Jun;207(6):391-4. 


\section{Case Reports in Oncology}

\begin{tabular}{l|l}
\hline Case Rep Oncol 2018;11:138-142 \\
\hline DOI: 10.1159/000487389 & $\begin{array}{l}\text { C } 2018 \text { The Author(s). Published by S. Karger AG, Basel } \\
\text { www.karger.com/cro }\end{array}$ \\
\hline
\end{tabular}

Ninomiya et al.: Prostate Basal Cell Carcinoma: A Case Report

8 Iczkowski KA, Ferguson KL, Grier DD, Hossain D, Banerjee SS, McNeal JE et al. Adenoid cystic/basal cell carcinoma of the prostate: clinicopathologic findings in 19 cases. Am J Surg Pathol. 2003 Dec;27(12):1523-9.

9 Begnami MD, Quezado M, Pinto P, Linehan WM, Merino M. Adenoid cystic/basal cell carcinoma of the prostate: review and update. Arch Pathol Lab Med. 2007 Apr;131(4):637-40.

10 Stearns G, Cheng JS, Shapiro O, Nsouli I. Basal cell carcinoma of the prostate: a case report. Urology. 2012 Jun;79(6):e79-80.

11 Dong A, Zuo C, Lu J, Wang Y. MRI, enhanced CT, and FDG PET/CT in basal cell carcinoma of the prostate. Clin Nucl Med. 2014 Aug;39(8):721-4.

12 Homma Y, Gotoh M, Kawauchi A, Kojima Y, Masumori N, Nagai A et al. Clinical guidelines for male lower urinary tract symptoms and benign prostatic hyperplasia. Int J Urol. 2017 Oct;24(10):716-29.

13 Simper NB, Jones CL, MacLennan GT, Montironi R, Williamson SR, Osunkoya AO et al. Basal cell carcinoma of the prostate is an aggressive tumor with frequent loss of PTEN expression and overexpression of EGFR. Hum Pathol. 2015 Jun;46(6):805-12.

14 Dinh KT, Yang DD, Nead KT, Reznor G, Trinh QD, Nguyen PL. Association between androgen deprivation therapy and anxiety among 78000 patients with localized prostate cancer. Int J Urol. 2017 Oct;24(10): 743-8.

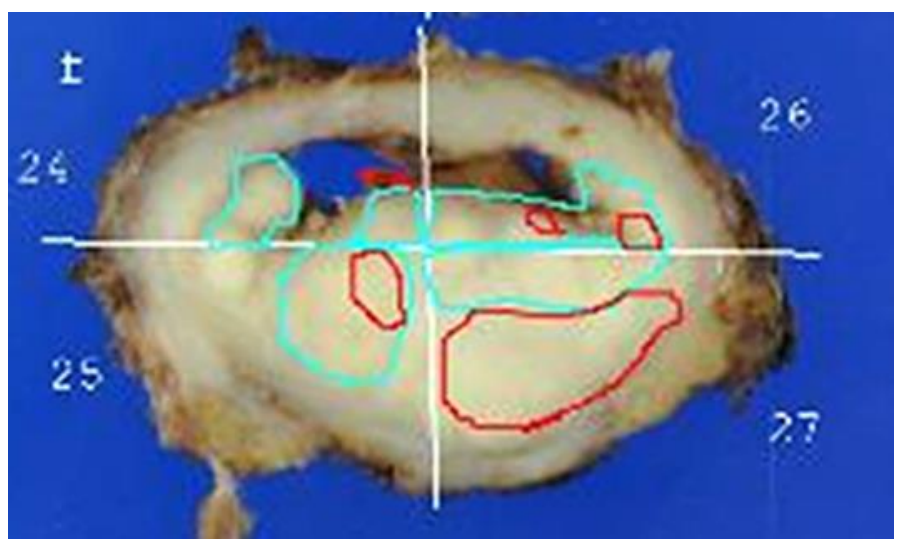

Fig. 1. Surgical specimens of the prostate. The red areas show prostate basal cell carcinoma.
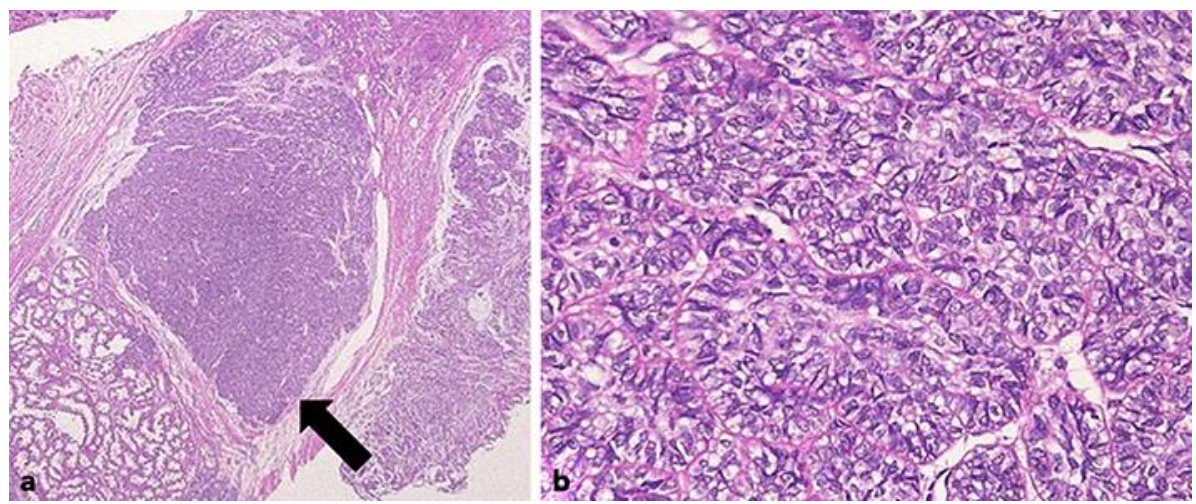

Fig. 2. HE stain. Prostate basal cell carcinoma is indicated by an arrow. 


\section{Case Reports in Oncology}

Case Rep Oncol 2018;11:138-142

DOI: $10.1159 / 000487389$

(C) 2018 The Author(s). Published by S. Karger AG, Basel www.karger.com/cro

Ninomiya et al.: Prostate Basal Cell Carcinoma: A Case Report
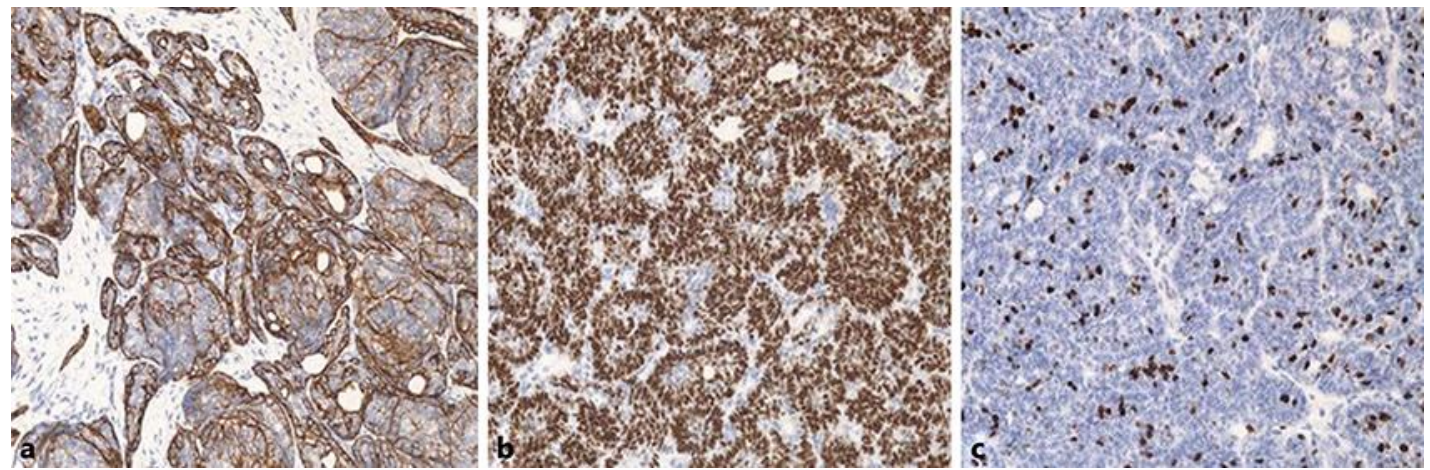

Fig. 3. Immunohistochemical analysis showed positive $34 \beta 12$ (a), P63 (b), and Ki-67 (c).
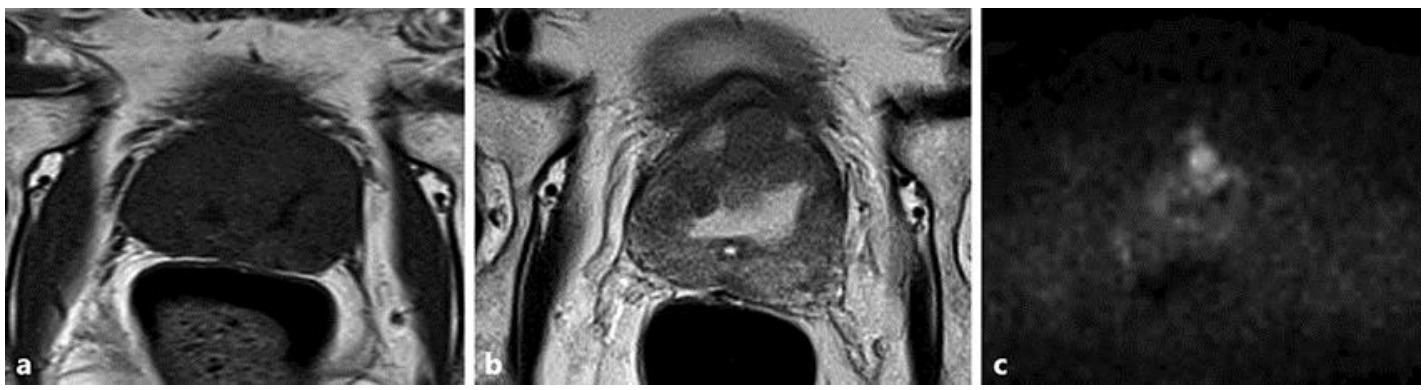

Fig. 4. MRI of the prostate: T1-weighted imaging (a), T2-weighted imaging (b), and diffusion-weighted imaging (c). 